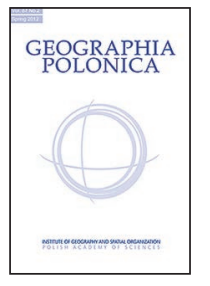

\title{
THE ROLE OF LOCALITY AND PLACE-SPECIFIC DEVELOPMENT PATHS IN CREATING SMART CITIES: THE EXAMPLE OF MIDDLE-SIZED HUNGARIAN CITIES
}

\author{
Ádám Szalai (D) - Szabolcs Fabula (D) \\ Economic and Social Geography Department \\ University of Szeged \\ Egyetem u. 2, 6722 Szeged: Hungary \\ e-mails: szalaiad@sol.cc.u-szeged.hu•Fabula.Szabolcs@geo.u-szeged.hu
}

\begin{abstract}
Smart cities have spawned a global discourse, which is, however, dominated by notions and theories originating from major metropolis regions in the Global North/West, as well as by quantitative approaches. Drawing on case studies from Hungary, this paper aims to reveal how place-specific factors influence smart-city development and to discover the characteristics of this development in the Hungarian context. For this purpose, qualitative research methods, namely a content analysis of policy documents and semi-structured expert interviews, were used. Based on the results, we distinguished four development paths: representative, stalled, organizational model, and focused smart city. Findings broaden the general understanding of smart-city development, providing policy recommendations for the future adaptation of the concept.
\end{abstract}

\section{Key words}

smart city $\bullet$ Hungary $\bullet$ case study $\bullet$ global-local context $\bullet$ medium-sized cities

\section{Introduction}

The smart city has become a leitmotif of urban development in the last two decades, rooted in the eco-city concept and the sustainable urbanism paradigm, placing technology and big data at the core of urban research and policy. As an inevitable outcome of the expansion of information and communications technology (ICT), there are wide-spread efforts all over the world to incorporate software-based solutions into the urban tissue, substantially transforming everyday city life. These tendencies are mirrored by the global triumph of the smart-city concept and by the mushrooming of local smart-city initiatives worldwide.

The smart city is not only a material reality, however, as it can also be considered a global discourse centered on the main idea that contemporary urban space is increasingly shaped by technological innovation, data-driven decision making, creativity, and entrepreneurship (Szalai, Á. 2020). From a geographical perspective, it is important to note that this 
is an open discourse. Since the smart city does not have a generally accepted definition or universal practical model, various actors in different geographical settings constantly renegotiate and reinterpret the concept. Thus, several scholars have pointed to the importance of social participation in smart-city development, calling smart-city advocates from different disciplines and geographical contexts to join the discourse and share their interpretations of the concept (e.g., Leitheiser \& Follmann, 2020). In addition, the smart-city discourse establishes connections between geographical scales, contributing to their reproduction. Therefore, smart-city research should pay attention to global as well as local processes and discuss their interrelatedness instead of separating them from each other (e.g., Varró \& Bunders, 2020).

This paper expands our knowledge about smart cities in two respects. First, following Shelton et al. (2015) and Joss et al. (2019), it is argued that being a global discourse, many phenomena related to smart cities cannot be perfectly explained without considering local circumstances. Each geographical place consists of specific features with regards to social institutions and economic life, influencing the local interpretations and implementations of global concepts such as the smart city. This is particularly true for medium-sized cities, and although these urban areas have several specificities compared to global metropolises, smart city discourse tends to focus on this latter group (Giffinger et al., 2007, Noori et al., 2020). Discovering and understanding place-specific factors are crucial to adapt the smart-city concept in order to cater to the needs of urban inhabitants, as necessary interventions in various cities might be completely different from each other. This brings us to the second point, that is, the global smart-city discourse has recently incorporated many ideas from the Global South (Datta, 2018; Mouton, 2020) and from Central Eastern European (CEE) post-socialist countries (Pašalić, 2021 et al; Sikora-Fernandez, 2018). However, as notions and theories from cities in the Global North/
West still dominate the discourse, it is worth conducting research in other parts of the world, such as the CEE area. Furthermore, in the international literature, there is an overrepresentation of quantitative research focusing on city ranking (Nagy et al., 2018; Giffinger et al., 2007) and of studies dealing with the technological aspects of smart cities.

Considering such issues, the present study focuses on local factors that influence smart-city development. Therefore, its main aim is twofold: to scrutinize the global understandings of smart cities from a Hungarian perspective, with special attention to the constitutive elements of the concept, and to enhance these understandings based on experiences from local case studies. In addition, this paper provides policy recommendations for the city-level adaptation of the smart-city concept, which are applicable in other contexts. For this purpose, smartcity developments in five Hungarian provincial cities (Debrecen, Győr, Miskolc, Pécs, and Szeged) are compared to each other. Therefore, this research applies a case-study approach using qualitative research methods, namely, content analysis of policy documents and expert interviews.

The rest of the paper is divided into four sections. First, the theoretical framework of the study is outlined, and a literature review on smart cities and CEE engagements with the concept is provided. In the second part, the research methodology and the casestudy areas are presented. The third section describes the empirical results on Hungarian smart cities and contrasts them with international experiences. Finally, the study ends with some concluding remarks and policy recommendations regarding the local adaptation possibilities of the smart-city concept.

\section{Global-local dualism in the smart-city discourse: A literature review}

Smart cities have evolved over the last two decades into a global scientific and policy discourse (Meijer \& Rodríguez Bolívar, 
2016; Echeberria et al., 2020). This discourse is extremely diversified, as illustrated by the connections between the 'smart-city' concept and other related scientific terms. At the initial stage of our research, such links were visualized by applying the co-occurrence analysis method in VosViewer, a software used to map out the interrelations between thematic fields, notions, phenomena, and the most frequently investigated geographic areas within a particular subject. The input data for the visualization derives from the Scopus publication database. The results for the keyword 'smart city' $(35,823)$ have been narrowed down twice: on the one hand by keywords: records related to urban research, such as urban planning, urban development, urban growth were selected (2079 results) and then by subject areas of social and earth sciences (800 results).
The generated CSV file was used as bibliometric data in the VosViewer software, in which the number of minimum occurrences was minimized to 50 during co-occurrence analysis. The output of the analysis consists of a bibliometric network diagram (Fig. 1). The extreme complexity of the co-occurrence network in our diagram corroborates the idea that the smart city does not have a single common definition and that the discourse around smart cities remains open and constantly changing (Neirotti et al., 2014; Varró \& Bunders, 2020). Furthermore, the diagram illustrates the interconnections among geographical places and scales, highlighting the overrepresentation of some areas (e.g., cities and countries) in the discourse and underlining the importance of geographical place and locality in smart-city development (Angelidou, 2017; Caprotti \& Cowley, 2019).

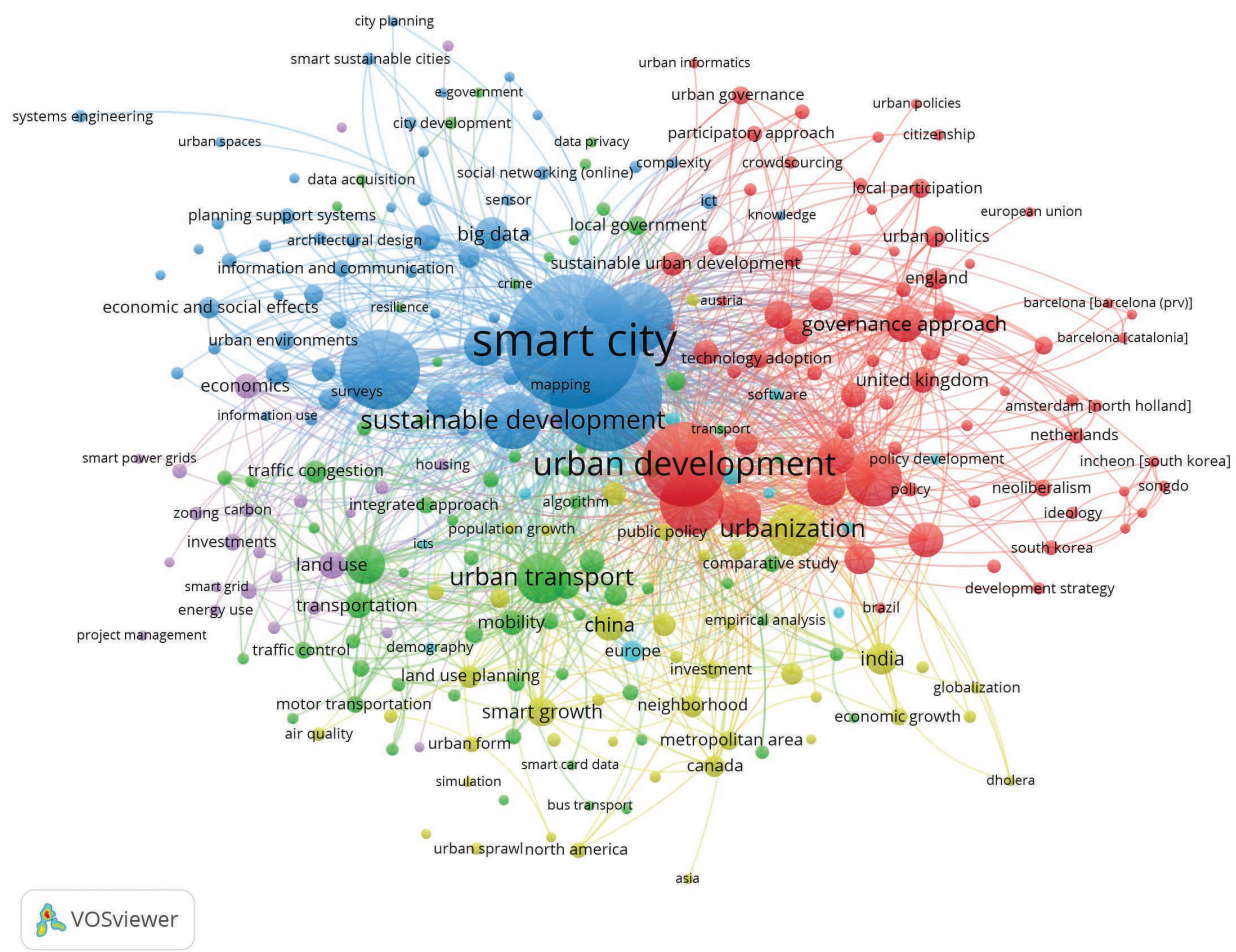

Figure 1. The bibliographic network of the term 'smart city' generated in VosViewer Source: compiled by the first author of the present article. 
In the remaining part of this section, these issues are discussed in a detailed manner.

Regarding the content of the smart-city concept, it seems clear that most of the definitions emphasize the primacy of ICT (Hall, 2000; Roy et al., 2001; Batty et al., 2012). For example, a 'smart city' is often attached to the 'intelligent city' concept, the latter focusing on skills and creativity as the primary resources in a knowledge-based economy, accentuating the increasing connectedness between knowledge and urban development (Yigitcanlar, 2015). Other authors (e.g., Vanolo, 2014; de Jong et al., 2015) have pointed to environmental protection and sustainability as the central elements of a smart city, as many smart-city projects have objectives such as decreasing and monitoring energy consumption or establishing and promoting alternative transport systems. According to another common idea, the burgeoning of smart-city developments is rooted in their potential economic benefits (Caragliu \& Del Bo, 2018). Consequently, urban policymaking based on smart devices primarily fosters the performance of a smart economy, including e-commerce, e-business, e-services, and software development, whereas other impacts can be considered positive externalities of smart development (Camero \& Alba, 2019). In contrast, humanistic and community-centered approaches call for enhancing social capital and applying community-led development (Caragliu \& Del Bo, 2018). Such development techniques are grounded in stakeholder-driven planning, which synchronizes corporate interests and cities' development goals through cooperation schemes or joint monitoring organizations. One of the prerequisites of such a development model is the availability of data obtained through resident satisfaction surveys and from utility companies, law enforcement agencies, health providers, and civil organizations (Szalmáné Csete \& Buzási, 2020). The factors that have been discussed in the present section are the most often cited elements of the smart-city concept. Critics of the global smart-city discourse (e.g., Söderström et al., 2014; Kitchin, 2015; Sharifi, 2019), however, have warned us that focusing only on the factors discussed above while neglecting others could lead to the fallacy that a smart city is a blueprint with 'one-size-fits-all' solutions. As they have argued, such a universalist approach can cause the failure of smart-city projects.

Thus, the smart-city concept can hardly be comprehended or successfully applied without investigating local social context. Ideally, smart-city projects are in a synergic relationship with each other, formulating a coherent city-scale strategy, and they are in line with other local development documents (Angelidou, 2017; Buck \& While, 2017). It should also be considered that, despite the potential of the smart-city concept, its successful implementation can be hindered by challenges related to organizational structures (Ruhlandt, 2018) and to political and administrative geographies (Coletta et al., 2019). Moreover, during the implementation of smart strategies, it is indispensable to analyze the local environment and to interpret and reconceptualize smart cities and other related notions (e.g., innovation) to adapt them to the needs of city dwellers. As part of this reconceptualization, local actors should be empowered to enable them to actively shape the future vision of their cities (Komninos et al., 2013). It is also important to grant equal rights to each social group to participate, making space for diversity in the smart-city discourse, as different actors can interpret smart development very differently (Desdemoustier et al., 2019).

Furthermore, smart-city development might become a source of conflicts, as this new policy paradigm can induce rearrangements of local power relations. This process might give rise to new socio-spatial inequalities, as local economic and political elites seek to establish and maintain the hegemony of their own smart-city narratives (Valdez et al., 2018; Bär et al., 2020; Breslow, 2020; Leitheiser \& Follmann, 2020). All things considered, we agree with the idea that a smart 
city is a discourse network, permeating and binding together various geographical scales (Joss et al., 2019; Szalai et al., 2021), in which local actors adopt global concepts, interpreting and reshaping them according to their local contexts but contributing to the global discourse as well. Therefore, to properly interpret the concept of a smart city and exploit its potential, it is always necessary to know the local context, especially the knowledge base of those involved in local development.

The importance of the local context is especially pronounced with relation to medium-sized cities (population of 100-500 thousand inhabitants). The role of public policy in creating an appropriate environment, the so-called smart city ecosystem (Ruohomaa et al., 2019), is even more dominant at the scale of medium-sized cities. Well-designed ecosystem allows private actors to participate as much as possible in the development process, while involving local residents, tourists, city authorities and other stakeholders, because the introduction of ICT-driven models often fails as they do not fit the characteristics and expectations of the different spheres of the city (Panagiotopoulou, M. et al. 2019). According to Hajduk, S. (2016), a city can be a smart city if it has the proper development documents and institutional system, intellectual resources, and infrastructure.

Considering local factors in smart-city discourse is also important in the case of postsocialist CEE cities. Recent studies underpin that smart-city developments in this region differ considerably from their Western European counterparts. There is a remarkable delay among Western and Eastern EU countries, furthermore, smart city solutions are still viewed as a novelty in the countries of the post-communist bloc, CEE cities are far from being leaders 'in terms of number, scale and scope of ongoing smart initiatives (Ibanescu et al., 2020). Smart cities in CEE are part of a current practice of planning and development, but the concept is not yet fully integrated in the management of cities (Ibanescu et al., 2020). The main differences are related to the market size of smart-city solutions, the performance of ICT sector investments, the existence of good smartcity examples and practices, the number of scientific publications related to smart cities, and residents' digital capabilities (Pašalić et al., 2021).

It is also typical of CEE countries that, in recent decades, with EU integration and adoption of the common cohesion policy, development practices have changed markedly, as reflected, for example, in the 'projectification' of urban planning and policy (Nagy, 2012). EU cohesion policy and the prospects of funding have been important drivers of the 'Europeanization' in the area (Varró \& Szalai, 2021). Drawing from their experiences in Poland, Gontar et al. (2013), for example, asserted that, as long as only unrelated and isolated projects are implemented, we can barely talk about the formulation of 'real' smart cities; according to their study, no Polish city met this criterion at the beginning of 2010s. Their results are corroborated by Kustra and Brodowicz (2016), who compared smart-city developments in Warsaw and Barcelona. They found that, while smart-city projects in Barcelona have arisen from a comprehensive city-wide smart development strategy, similar projects in Warsaw show inconsistency and depend on external funding opportunities, focusing almost exclusively on public transport and energy efficiency. All in all, one of the main challenges for smart-city development in the CEE context is to join the 'smart/intelligent' label to potential funding opportunities, already existing resources, general development objectives, and local needs. Furthermore, although the national and local authorities in CEE countries have largely adopted EU funding guidelines and methodological recommendations, strategic urban planning in this region is still hampered by project-based funding, short-term financial interests, and the fact that national and local governments often adjust their policies in response to electoral cycles (Sikora-Fernandez, 2018). 
Another critical point in CEE smart-city development is the issue of public participation and the related governance and coordination schemes. One of the obstacles to broad public participation is that a significant part of the population in these countries has limited knowledge of the smart-city concept and the potential benefits of ICT tools, as recently demonstrated by case studies from Sankt Petersburg (Vidiasova \& Cronemberger, 2020) and from Kosice and Maribor (Klimovsky et al., 2016). Another challenge of smart-city development is the relatively low level of local autonomy and competence. In Hungary, for instance, an extensive recentralization process has been occurring since 2010, which results in the decreasing administrative and financial independence of local municipalities, strengthening political clientelism, and growing influence of the national government on smart-city development (Pálné Kovács, 2019; Varró \& Bunders, 2019). The limited decision-making power of local governments can also be observed in Czechia, where various ministries are responsible for development; thus smartcity programs can only be implemented through cooperating and bargaining with these national-level actors (Janurova et al., 2020). To conclude this section, greater public involvement, democratic participation, local autonomy, and cooperation between local municipalities should be encouraged in CEE smart-city development (Kollar et al., 2018). Thus, there is a need for research practices that bring the ideas and conceptions of local actors to the fore. Considering the lessons from the literature review above, the present paper investigates the smart development plans of Hungarian middle-sized cities, addressing the following research questions:

1. What are the characteristics of the interpretation and implementation of the smart-city concept in middle-sized Hungarian cities?

2. What are the lessons of these experiences for smart city discourse and smart city developments?

\section{Research methodology and case-study areas}

\section{Research methods}

As seen in the theoretical section, in the present paper, the smart city is considered a global discourse, which is nonetheless inseparable from local material conditions. Therefore, a subjectivist-constructivist methodological approach was selected for this study, according to which not only the directly visible and verifiable features of reality can be explored but also the underlying meanings arising from the actions and relationships of individual actors and organizations (Gelei, 2006).

The present study deals with smart-city developments implemented in a group of Hungarian cities, as well as with the local interpretations of the smart-city concept. Methods for data collection include the content analysis of secondary sources and the analysis of semi-structured expert interviews. The secondary sources used include nationaland local-level policy documents. Nationallevel documents (e.g., the Digital Welfare Program of Hungary 2.0) are important because, as demonstrated in the literature review, in CEE countries, national governments play a crucial role in smart urban development. Local-level document types include the Urban Development Concept (UDC) and the Integrated Urban Development Strategy (IUDS): The former provides a long-term outline for the development of a particular city, whereas the latter sets out how the financial resources allocated to the objectives of the current European Union programming period are to be spent at the local level. Besides the above two, other documents related to smart development include the Sustainable Urban Mobility Plan (SUMP) and the Sustainable Energy and Climate Action Plan (SECAP), as they deal with issues that constitute important elements of the smart approach, such as transport, energy efficiency, and climate protection (Tab. 1). The focus of the content analysis was threefold, including (1) the interpretations of the smart-city 
concept, (2) the main objectives of local development with regards to smart cities, (3) and connections of smart-city initiatives with other policy areas.

The group of the interviewees consisted of employees working at national-level government agencies (three individuals), researchers dealing with smart cities (3), private entrepreneurs (3), and local smart-city executives (3). The involvement of these experts increased the relevance and reliability of our study, as they had considerable practical experience in the implementation of smart-city projects. A total of 12 semi-structured interviews were conducted face to face or by telephone between September and December 2019. Some of the interviewees were approached directly through personal meetings at thematic conferences or via email/phone after spotting them in the media, whereas others were recruited by using a snowball sampling method. The length of the interviews ranged between 25 and 95 minutes, with an average of 65 minutes. The main aim of the interviews was to discover how the interviewees had become involved in smart-city development, identify the main goals of local actors with respect to smart cities, and determine the main conflicts and contradictions in Hungarian smart-city development. All interviews were recorded and transcribed verbatim. As an initial stage of analysis, open coding of the interviews was carried out, which involved reading the transcripts line by line, applying open codes, and identifying the main ideas and concepts related to the research questions (Sallay \& Martos, 2018). During the process, every line of the transcripts was analyzed carefully to reveal what information the line in question contained with regards to the original research question. Then, the initial codes (ideas) were grouped into categories. As the interviewees belonged to different spheres of the economy and society, they emphasized different aspects in relation to smart-city initiatives. Analyzing the policy documents and interviews, in this study, we intended to reveal the similarities and differences between the ideas of various actors.

\section{Case-study areas}

For the purpose of our study, five Hungarian cities were selected as case-study areas. This selection can be justified by the comparability of these cases: All of them are major urban centers in Hungary, although they can be considered medium-sized cities at a European scale (Dijkstra \& Poelman, 2012). After Budapest, the capital city, all of them belong to the second level of the settlement hierarchy in Hungary. Their functional roles show considerable similarity, but their geographical remoteness from each other (Fig. 2) precludes any kind of economic shadow or agglomeration effect. Furthermore, these cities are suitable for smart-city research in Hungary due to their very size, as they have a complex and service-based economic structure, and serve as centers of higher education, and have a high innovation potential and a large, skilled workforce pool (in Debrecen, Miskolc, Pécs, and Szeged) or less human capacity but internationally strong and locally well-embedded industrial bases (see Győr, where a major Audi automobile manufacturing plant is located). Another selection criterion was that each case-study city should have a well-identifiable smart-city initiative, whether a comprehensive city-level development strategy or separate projects. It should also be noted that, in the last two decades, these cities were among the main beneficiaries of policies (e.g., the Polus Program and the Modern Cities Program) that aimed to dynamize the economic life in areas outside Budapest and decrease regional inequalities in Hungary (Rechnitzer, 2019). As a result of neoliberal regional policies, the concentration of creative industries is rising in Hungary; thus, the case-study areas form a circle of cities in the country that have the potential to attract creative industries and labor outside Budapest through their cultural endowments and roles as educational centers (Kovács et al., 2019). It is also worth noting that because all these cities are located in the same country, the national policy context and administrative 


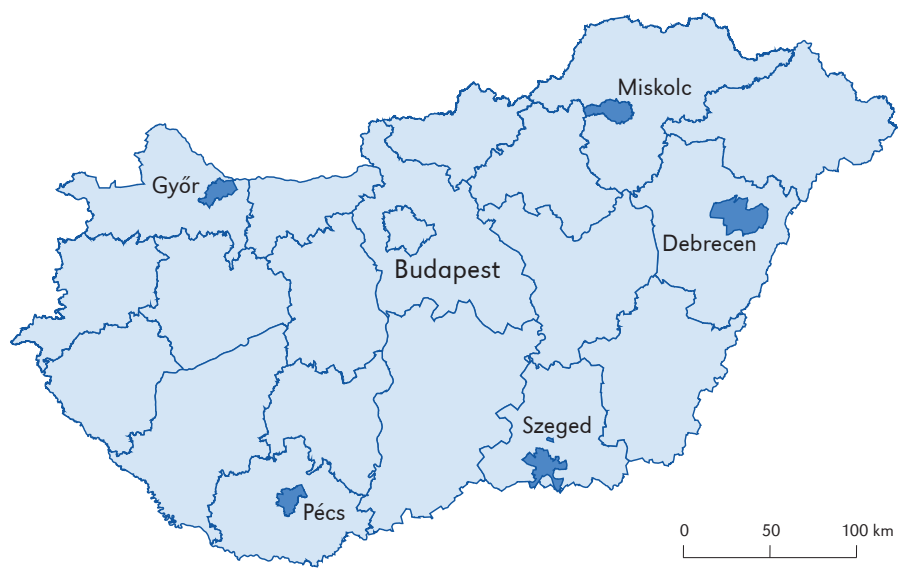

Figure 2. The location of the case-study cities within Hungary

Source: compiled by the first author of the present article.

Table 1. Basic data on the case-study areas and their smart city-related characteristics

\begin{tabular}{|c|c|c|c|c|}
\hline Case-study city & Population & $\begin{array}{c}\text { Analyzed policy } \\
\text { documents }\end{array}$ & $\begin{array}{l}\text { Institutional } \\
\text { background }\end{array}$ & $\begin{array}{l}\text { International } \\
\text { activity }\end{array}$ \\
\hline Debrecen & 201,432 & $\begin{array}{l}\text { UDC, IUDS, SUMP, } \\
\text { SECAP, Smart-City } \\
\text { Strategy }\end{array}$ & EDC Debrecen & \\
\hline Szeged & 160,766 & $\begin{array}{l}\text { UDC, IUDS, SUMP, } \\
\text { SECAP, Smart-City } \\
\text { Strategy }\end{array}$ & $\begin{array}{l}\text { Administered by local } \\
\text { municipality }\end{array}$ & $\begin{array}{l}\text { CIVITAS } \\
\text { Elliptic, } \\
\text { Urban Innovative } \\
\text { Actions }\end{array}$ \\
\hline Miskolc & 154,521 & $\begin{array}{l}\text { UDC, IUDS, SUMP, } \\
\text { SECAP, Smart-City } \\
\text { Strategy (not publicly } \\
\text { available) }\end{array}$ & Miskolc Holding & $\begin{array}{l}\text { Remourban, } \\
\text { Rebus, } \\
\text { TRAM }\end{array}$ \\
\hline Pécs & 142,873 & $\begin{array}{l}\text { UDC, IUDS, SUMP, } \\
\text { SECAP }\end{array}$ & - & \\
\hline Győr & 132,038 & UDC, IUDS & $\begin{array}{l}\text { Administered by local } \\
\text { municipality }\end{array}$ & \\
\hline
\end{tabular}

Notes: UDC = Urban Development Concept; IUDS = Integrated Urban Development Strategy; SUMP = Sustainable Urban Mobility Plan, SECAP = Sustainable Energy and Climate Action Plan

Source: compiled by the first author of the present article based on TeIR (Spatial Information System, Hungarian Central Statistical Office).

structure is the same for each of them, making the comparison more feasible. Consequently, although this comparison is not an international one, our objective is not to draw a general model of smart urbanism in Eastern Europe but to explore local specificities that influence smart urban development in the region.

\section{Discourses related to smart city development in the regional centers of Hungary: Results of the empirical research}

Our analysis in selected Hungarian cities confirmed that the local context substantially influences smart-city developments. 
After reviewing the main projects, it became clear that these cities took significantly different development paths from each other; that is, it is not worth subjecting smart-city ideas to a coherent pattern-even in a relatively small country like Hungary. Although there are also central efforts for smart developments in Hungary, the motivations of becoming a smart city vary on the local level. Expert interviews revealed that, although the global elements of smart-city discourse are also integrated into the concepts of local stakeholders, their mindset is strongly affected by local development needs and opportunities. During the elaboration of the interviews, we initially identified 21 relevant topics, but in the second round of the analysis, some topics were merged with existing topics due to their relevance or the similarity of their content. The topics were classified along two dimensions because we found through the processing of the interviews that they are related to the content of the topics that emerged. One dimension concerns the relationship of interviewees to smart-city developments, and the other involves the factors associated with different territorial levels, which influence the implementation of smart-city developments (Fig 3).

The interviewees were grouped by their attitudes as either skeptics or proponents. The skeptics doubt the emergence of the smart-city concept in Hungary. In their point of view, most Hungarian cities interpret the prospects of smart cities in a limited nature, which can be explained by Hungarian development policy, which focuses on representative 'hard' developments. This view lacks the holistic approach to the city as a system and uses the term 'smart city' as a buzzword, taking the concept as a political product.

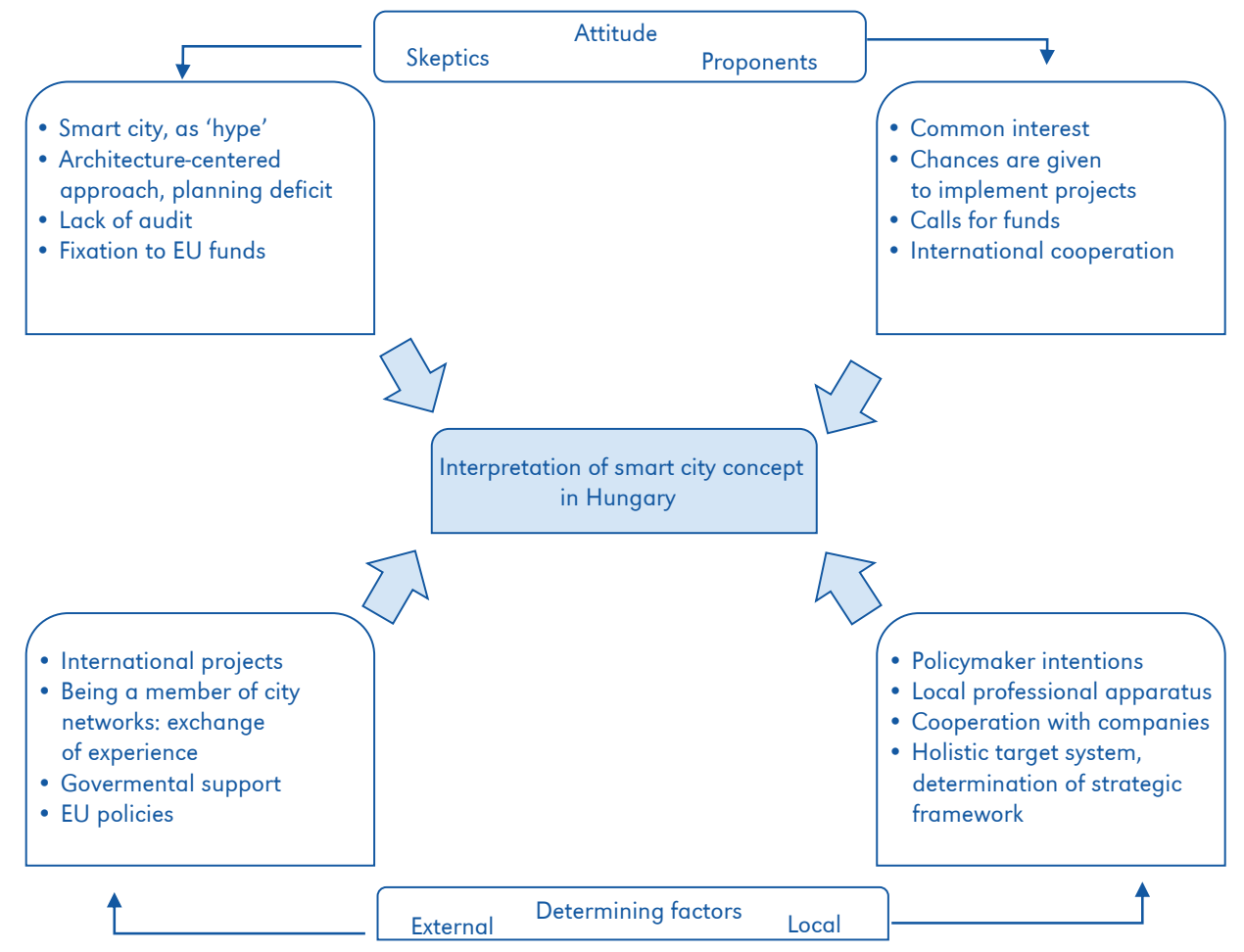

Figure 3. The relationship of the interviewees with the smart-city concept and the most important influencing factors of smart-city development in Hungary. 
On the project level, it is limited to infrastructure developments such as the creation of public Wi-Fi networks, video surveillance systems, or city cards. According to our interviewees, these developments do not contain fundamental novelty and are loaded with privacy concerns. City card systems demand widespread integration of local services, and the government should spark interest among residents about using the system. However, the implementation of smartcity projects is fundamentally influenced not only by budgetary resources but also by the existence of local knowledge and information, which requires a systematic audit and situation assessment of the given settlement. Otherwise, inconsistent and isolated projects will be executed or even canceled (see the examples of Győr and Pécs for one and the other scenario below).

As some interviewees stated, neither the quality of regional policy in Hungary nor the fragmented municipal structure is beneficial in the implementation of successful smartcity projects, as the question of 'critical mass' is raised: ${ }^{1}$ Is it necessary or even possible to define a critical mass (population, which represents the potential size of the smart-services market) against which smartcity investments become economically sustainable? In view of another aspect of 'critical mass', the 'mass' of available smart services makes a city smart. The smart city as a notion, because of its fuzziness, remains difficult to translate into a political product, which is why some policymakers are not motivated to execute smart projects. One of the interviewees from the market sphere saw the solution in the creation of a rating system; cities should tender for dedicated funds, implementing projects linked to each other to obtain a 'smart-city title'. However,

\footnotetext{
1 Currently, there are 3155 legally independent municipalities in Hungary, and in one third of them, the population is less than 500. Apart from the capital, Budapest, which has 1.7 million inhabitants, there are only seven cities that reach population size of 100,000 , among which Debrecen is the only one above 200,000 .
}

this may lead to the phenomenon of 'urban labeling' identified by Hollands (2008), in which the smart city serves as means of communication that covers the gap.

Skeptics have mostly pointed out that many cities consider the smart city as a goal to be achieved, although it should be used as a tool to implement synergistic projects in a specialized way, concentrating on focus areas. However, doing so requires good examples to follow so that cities can learn from each other and implement the best solutions from the same supplier using cost-effective solutions. Furthermore, instead of a budgetary approach, market participants would expect cities to have a business mindset that would guarantee the economic sustainability of developments. This idea is based on smart-city solutions that serve real community needs.

Conversely, proponents highlighted the potential of implementing the smart-city concept, as data collection and processing offer immense opportunities to make smart cities better-managed cities. According to this group, data-based urban development can represent a tool of local urban policy and decision making that manages the subsystems (e.g., land use, economic development, and transport) in a unified GIS database. Thus, the opportunity arose to rethink city development strategy documents (e.g., IUDS), in which process engineering and the response-level solution of urban problems are given greater emphasis. Furthermore, the elements of the smart-city concept can be linked to horizontal principles, such as sustainable development or equal opportunities. Proponents mentioned the existence of a proper institutional background as a crucial issue both in the case of strategy framing and implementation, for which several positive examples were highlighted. In Debrecen, the Smart City Working Group at the municipality-owned Debrecen City and Economic Development Center (EDC) works closely with the city administration. They are responsible for developing and reviewing the city's smart-city 
strategy, partnership cooperation, project management, and socialization.

In Miskolc, the Miskolc Holding group of companies unifies public utility service providers and IT activities and is responsible for project implementations commissioned by the local government, which applies for development funds. According to the interviewees, experience shows that smart urban development embedded in an appropriate organizational framework can function more effectively as a result of the existence of competencies, the appropriate allocation of tasks, and the efficient mobilization and use of funds.

Proponents also suggested that the EU and national (such as the Modern Cities Program) strategic frameworks also promise significant fundraising potential for smartcity development, but cooperation between stakeholders is indispensable. The key is an effective process of reconciling interests and the willingness on the part of the city administration, as well as the creation of a local strategy, which can also be a useful input for international tenders. Taking part in international projects and city networks helps in the implementation of smart-city projects. Examples are the cities of Szeged and Miskolc. The former executed several projects in cooperation with international partners in the field of public transport (such as onboard vending machines, battery-powered trolleybuses, data consumption, and weight-based passenger counting), and cashless payment solutions. Miskolc's international activities include know-how transfer and the development of cycle transport-supporting applications.

Beyond unraveling the general factors influencing smart-city development in Hungary, we also investigated how these factors prevailed in chosen sample areas and how these cities performed as smart cities. Although Hungary is a relatively small country that has a national policy framework regarding smart development (e.g., see Government Decree 56/2017 [III. 20.] and 252/2018 [XII. 17.]), the motivations and circumstances of creating smart cities vary on the local level.
Based on an analysis of expert interviews and secondary data sources, we identified four different development paths:

- representative smart city-Győr;

- stalled smart city-Pécs;

- organizational model-Debrecen, Miskolc; and

- focused smart city-Szeged.

Győr started smart-city developments in the conjuncture period, which emerged around the organization of an international sports event called the European Youth Olympics Festival in 2017. The agreement between the municipality and the E.ON energy company (For Green Olympic Games and Energy of Tomorrow, Smart City Agreement) aimed at implementing sustainable investments in terms of energy. As part of this plan, a new dormitory wing, a solar park, and public lighting developments were completed. The energetic focus remained later: The local district heating provider introduced smart metering and installed smart poles in the city's parks. However, the intention of becoming a smart city, which appeared several times in the beginning on a rhetorical level, was not embodied in the strategy, as other elements of the smart-city concept were not included in the toolbox of local development policy, such as open data platforms or community planning alternatives. A competent interviewee from Györ emphasized that some projects were executed incidentally, with the smart city interpreted only by subsystems, in connection with the principle of a compact city. "As far as I can judge, the smart-city concept died in Györ. These developments only have political importance. That is why they are ad hoc" (research fellow, Győr).

Pécs relies on the smart-city concept in its IUDS. However, due to the political and financial instability in the city, together with difficulties of structural change stemming from the city's industrial past, the development of the city based on smart principles stalled, limited to the development of a local bus schedule and emergency mobile app, as well as the procurement of electric buses. 
Debrecen and Miskolc both have professional organizations responsible for smartcity developments, which, thanks to their knowledge base and human resources, are at the forefront considering both the strategic-thinking and project levels in Hungary (such as e-ticket and intelligent parking systems, biogas plants, and smart meters). The organizational background guarantees participation in international projects (see Miskolc) and self-reflection (Debrecen's smart-city strategy was adopted after three revisions; Miskolc's is not yet public), so these cities have a definite vision of future developments, unlike Pécs and Györ.

Szeged introduced the smart-city concept in 2016. Since then, the city has implemented pilot projects, which have payback potential in two aforementioned focus areas (i.e., public transport and cashless payment solutions) to achieve social benefits. The city's smart-city developments are in line with the third specific goal from IUDS: "Increase the city's capability to maintain its population, by development of public spaces and urban environment, revitalization of deteriorated areas, integration of new areas, and support sustainable transportation systems" (IUDS page 11). The document highlighted that Szeged, a city with county rights, intends to ensure a better, more efficient connection of infrastructure systems and services by applying smart technologies, applying the tools of the 'smart city' concept (IUDS page 12). The cited objectives also appear in the target system of the city's smart-city strategy as follows: "Szeged, Cashless City" and "More Livable Szeged for Urban Citizens" (Szeged Smart-City Concept, page 32).

Skeptics and proponents both underlined that the upcoming 2021-2027 EU programming period will have new fund-allocation structures and objectives, of which innovation and environmental protection stand out. With regard to IUDS for the current cycle, which expired in 2020, the question arises: What is really needed, a revision of existing strategies or the creation of development documents on a completely new basis (based on smart strategy and principles) that aim at fostering urban technological innovation? Therefore, there is a need for a comprehensive strategic approach and broad social inclusion so that different actors can work together to define what they mean by smartcity development at the local level (Leitheiser \& Follmann, 2020). For this reason, it remains an important area of research to examine the links between smart-city initiatives and the activities of the administrative and political actors associated with them.

\section{Conclusions and policy recommendations related to smart-city developments}

In this paper, through an analysis of case studies from Hungary, we have shown how location-dependent factors and the specific context result in different development paths in terms of smart urban development. We argued that the smart city is a global discourse, which basically focuses on the (large) cities of the Global North, can be better understood by knowing about local characteristics.

In response to our first research question, which focuses on the characteristics of Hungarian smart city interpretation and implementation, first of all, it is important to note that the commitment of the central and local state is of crucial importance regarding local development projects. This is mainly because of hierarchical patterns of governance (Masik et al., 2020) as well as centralstate and EU development policies, which factors are appreciated in the fundamentally under-resourced CEE context (Varró \& Bunders, 2020). Hungarian settlements followed different paths compared to the general global narrative and to each other as well. Our results support the findings of previous works (see Calzada, 2017; Caprotti \& Cowley, 2019) that smart-city thinking cannot be lumped together, especially on the scale of medium-sized cities in Europe, which constitute a specific group. It can be observed, for example, that some developments are not 
only based on purely 'smart' intentions but on thematically more specific, well-defined local goals and aspirations that started the smart development process (as in the case of Miskolc for the protection of the local environment and joining the green cities movement). The technocratic, ICT-dominated model often emerges in the literature (Yigitcanlar et al., 2018; Kitchin et al., 2019). However, in Hungary (at least in the case of the studied cities), this is not perceptible. In the case of the examples in Hungary discussed in this paper, the fund absorption capability in specific settlements plays an important part, which is largely determined by the quality of the local policy and the development path chosen by the city administration.

Institutional path-dependencies and centralized urban policy practices often shift the focus to representative, mainly hard infrastructure developments. As a consequence of the dependence on EU funds, cities strive to maximize available EU tenders and find potential development partners. Thus, in contrast to the 'desirable' development process (in which projects are preceded by a situation analysis and assessment in the strategy-framing process), one can often encounter examples in Hungarian development practice (e.g., in Miskolc among the cities examined) in which it is possible that cities call for funds at first and then create a development strategy.

Networking and collaboration were generally common topics in the expert interviews. On the one hand, the participation of Hungarian settlements in cooperation programs was found to be low in both Hungarian and international comparisons which seems to be an obstacle in terms of the sharing of good practices. As a result, the chances of Hungarian cities-which already struggle with a lack of resources (e.g., fewer innovation- and technology-oriented enterprises and a lower number of specialists in smart-city developments)-to implement a larger international project are further reduced. The experience is similar in the Polish context, where lack of resources, knowledge, experience and technical capacity, also forces cities to consider implementing smart solutions thoroughly. However, ITI programs (such as in the Gdańsk-Gdynia-Sopot region) are a potentially forward-looking examples, which appropriate smart approach on regional level regarding issues (e.g. transit, thermo-modernization) which affect neighbouring municipalities (Masik et al 2020).

On the other hand, the coordination of the local government and the market side is also a cardinal issue from a development point of view, especially in the increasingly centralizing Hungarian governmental structure, in which local governments have limited competencies (Pálné Kovács, 2019).

In order to answer the second research question, we want to contribute to the smart city discourse with a PESTLE analysis (Fig. 4), based on the work of Kustra and Brodowicz (2016), in which we summarized the most important influencing factors of smart-city development in Hungary. PESTLE analysis is an upgraded version of the PEST analysis, further developed by taking into account the legal framework and environmental factors. It is important to note that these political, economic, social, technological, legal, and environmental factors reflect the situation in Hungary, but according to our assumption based on the smart-city literature, many of them can be applied not only in Hungary but in other CEE countries and globally as well.

Based on the lessons learned, we suggest a series of measures aiming at increasing the success of future smart initiatives.

- There is a need for a more sophisticated foundation of such developments, including not only the implementation of projects but also the long-term maintenance and continuous filling of the smart services offered, which basically requires viewing urban tasks as a service provided to residents. A potential tool for this purpose could involve helping municipalities create a problem map to match their needs and identify smart solutions that offer possible alternatives with a solution map. In creating this tool, residents need 


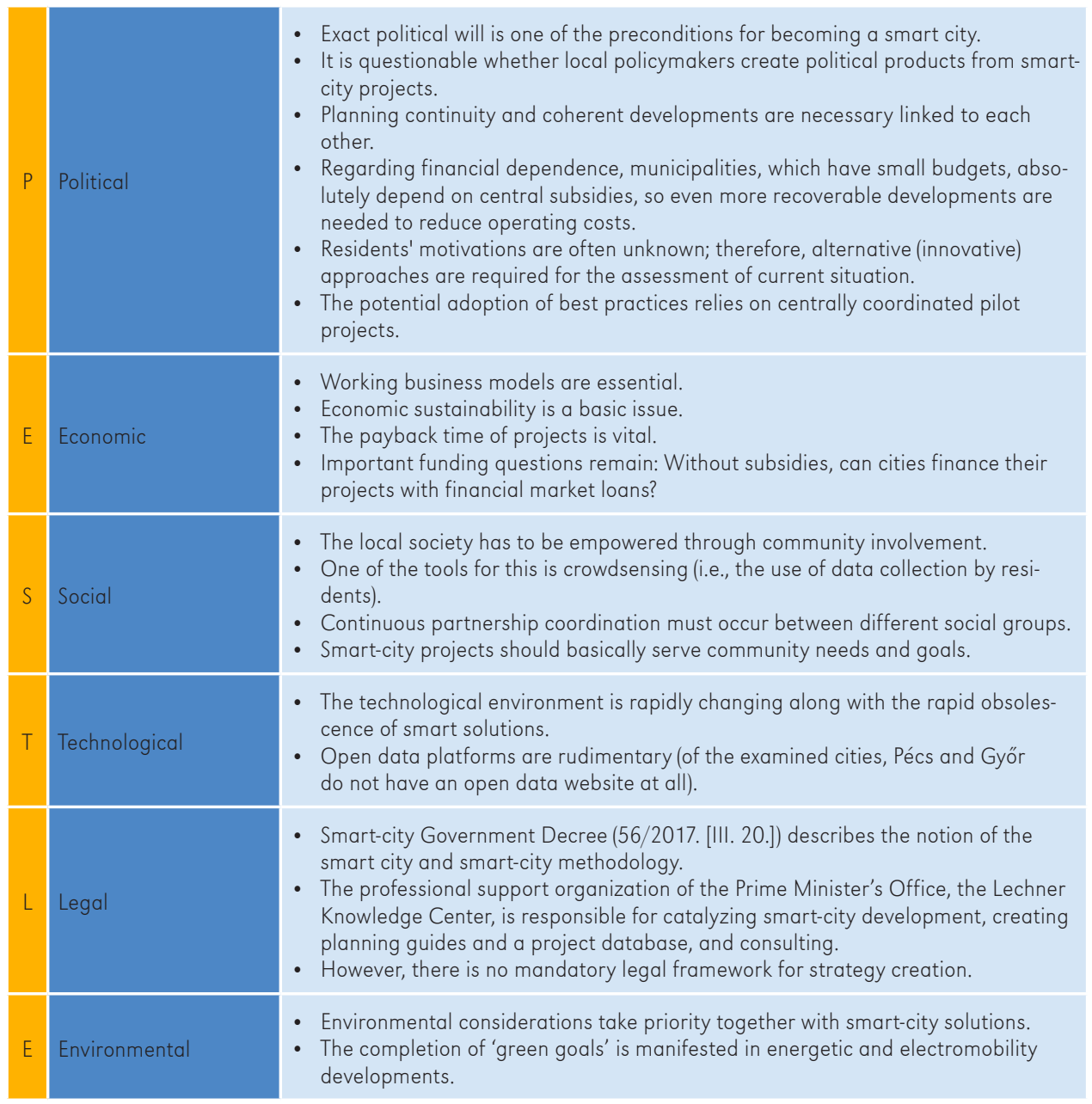

Figure 4. PESTLE analysis of influencing factors considering smart city development in Hungary.

Source: compiled by the first author of the article

to become active actors. Furthermore, other city users, such as tourists, should be involved not only as data providers via smart devices but as locally embedded 'experts' (Calzada, 2017), thus increasing the embeddedness of different needs in developments. Nevertheless, as we discussed above in the literature review, residents trust smart devices less; thus, a development policy ought to consider providing information to people and sensitizing them. Smart cities demand smart management and planning with a holistic approach. Hence, cities have free access databases (Ogrodnik, 2020) to make decisions by using locally collected data and GIS databases and involving local interest groups according to a well-founded educational and communication strategy. The awareness of the local population and the involvement of actors legitimize the interventions. Therefore, bottom-up initiatives and the incubation of local businesses should be further supported.

- Magnaghi et al. (2021) argue, that the main impediment to the smart strategy 
execution for medium-sized cities concerns the administrative fragmentation, which hinders strategic decisions capable of involving a larger area. Consequently, smartness should be treated not as a punctual phenomenon but with a holistic outlook. From our case studies, the City of Debrecen serves as a good practice, where the Smart City Working Group at the municipality-owned Debrecen City and Economic Development Center (EDC) works closely with the city administration, providing a well-functioning institutional framework for smart development.

- Municipalities with knowledge and institutional deficits need models that are already functioning. Implementing working models is also crucial for testing operational models: The model based on the sale and purchase of services coming from external partners must be replaced by a real operational and (also economically) sustainable model, which determines who is responsible for operating a given smart development, how incoming data will be processed, and for what purposes and on which rate the smart services will be upgraded. To control this aspect, a dedicated management organization is needed, the operation of which is based on the coordination between municipalities and government levels. These types of development should be given priority in terms of support.

- The basis for creating and maintaining successful smart cities consists of local knowledge and process design, which require an organizational background. Experience shows that cities that have an apparatus responsible for smart developments are more successful. Therefore, the further training of municipal professionals and the extension of the already announced "digital regional development expert" training should be strengthened. The advantage for latecomers of CEE countries is that they can learn from the experience of pioneers and early investors; the most advanced ICT infrastructure available can be deployed, and proven solutions can be applied.
- Smart-city strategies must include transparent funding frameworks for the local government, the central and/or regional government, and market participants, especially regarding the involvement of the latter in terms of which products and services they can contribute to the development goals. Consequently, it is advisable to allocate dedicated smart-city funds for the development of smart services.

- As a result of COVID-19, the expanding teleworking phenomenon will accelerate the digitalization of everyday life and work, which is a key area of support for European Union policy. The epidemic crisis could accelerate the implementation of new developments that improve the population's quality of life, which could potentially be funded by the EU's 20212027 budget. The most important task of urban researchers and urban planners is therefore to participate in the planning of smart cities in a rapidly changing environment, striving to reduce negative spatial and social impacts (such as the intensification of suburbanization and private transport, as well as the exclusion of lower-status social groups) and to minimize the spread of the virus (e.g., by sharing real-time data as quickly as possible using intelligent camera systems [Kunzmann, 2020; Kummitha, 2020]).

- Concerning the possible tasks of geographers in the field, researchers should perform vital role even in practice and in the communication of smart developments. Research in urban studies can establish scientific basis of potential projects, which lead to efficient project prioritization. Scientists need to enter communication and dissemination process both before and after the practical implementation, in order to make potential users, the urban residents to be able to understand the mechanism of smart developments, and to realize their benefits in everyday life.

- Overall, the basis of creating well-functioning smart cities is the capability to keep balance between business interests 
and innovations, meanwhile finding the right project prioritization. With this research we have dedicated interest on Hungarian experience and its ramifications for understanding smart city not as a petrified paradigm but as a process of constantly changing way of making urban policy.

\section{Acknowledgements}

The authors would like to thank the anonymous reviewers for their comments and suggestions on expanding the research topic.
This work was partly supported by the New National Excellence Program UNKP-19-3SZTE-273 of the Ministry of Innovation and Technology of Hungary.

Editors' note:

Unless otherwise stated, the sources of tables and figures are the authors', on the basis of their own research.

\section{References}

Angelidou, M. (2017). The role of smart city characteristics in the plans of fifteen cities. Journal of Urban Technology, 24(4), 1-28. https://doi.org/10.1080/10630732.2017.1348880

Bär, L., Ossewaarde, M., van Gerven, M. (2020). The ideological justifications of the Smart City of Hamburg. Cities, 105, 102811. https://doi.org/10.1016/j.cities.2020.102811

Batty, M., Axhausen, K., Fosca, G., Pozdnoukhov, A., Bazzani, A., Wachowicz, M., Ouzounis, G., Portugali, Y. (2012). Smart cities of the future. The European Physical Journal, 214, 481-518. https://doi.org/10.3929/ethz-b-000061793

Breslow, H. (2020). The smart city and the containment of informality: The case of Dubai. Urban Studies, 58(3), 471-486. https://doi.org/10.1177/0042098020903233

Buck, N.T., While, A. (2017). Competitive urbanism and the limits to smart city innovation: The UK Future Cities initiative. Urban Studies, 54(2), 501-519. https://doi.org/10.1177/0042098015597162

Camero, A., Alba, E. (2019). Smart City and information technology: A review. Cities, 93, 84-94. https://doi.org/10.1016/j.cities.2019.04.014

Calzada, I. (2017). The techno-politics of data and smart devolution in city-regions: Comparing Glasgow, Bristol, Barcelona, and Bilbao. Systems Journal, 5(1), 1-18. https://doi.org/10.2139/ssrn.2920219

Caprotti, F., Cowley, R. (2019). Varieties of smart urbanism in the UK: Discursive logics, the state, and local urban context. Transactions of the Institute of British Geographers, 44(3), 587-601. https://doi.org/10.1111/tran.12284

Caragliu, A., Del Bo, C.F. (2018). Smart innovative cities: The impact of Smart City policies on urban innovation. Technological Forecasting and Social Change, 142, 373-383. https://doi.org/10.1016/j.techfore.2018.07.022

Coe, A., Paquet, G.,Roy, J. (2001). E-governance and smart communities: A social learning challenge. Journal on Social Science Computer Review, 19(1), 80-93. https://doi.org/10.1177/089443930101900107

Coletta, C., Heapy, L., Kitchin, R. (2019). From the accidental to articulated smart city: The creation and work of 'Smart Dublin'. European Urban and Regional Studies 26(4), 349-364. https://doi.org/10.1177/0969776418785214

Datta, A., Odendaal, N. (2018). Smart cities and the banality of power. Environment and Planning D: Society and Space, 37(3), 387-392. https://doi.org/10.1177/0263775819841765 
Debrecen Megyei Jogú Város Fenntartható Energia-és Klímaakcióterve (SECAP). Retrieved from: https://www.debrecen.hu/assets/media/file/hu/9347/debrecen-energia-es-klimaakcioterve-secap.pdf [01 June 2020]

Debrecen Megyei Jogú Város Fenntartható Városi Mobilitási Terve (SUMP). Retrieved from: http://portal.debrecen.hu/upload/File/Hirek/Mobilitasi_terv_\%20tarsadalmi_egyeztetes.pdf [01 June 2020]

Debrecen Megyei Jogú Város Integrált Településfejlesztési Stratégiája. Retrieved from: https://www.debrecen.hu/assets/media/file/hu/7308/strategia.pdf [01 June 2020]

Debrecen Megyei Jogú Város Smart City Stratégiája. Retrieved from: http://smartcity.debrecen.hu/docs/Debrecen\%20Smart\%20City\%20Strategia.pdf [01 June 2020]

Debrecen Megyei Jogú Város Településfejlesztési Koncepciója. Retrieved from: https://www.debrecen.hu/assets/media/file/hu/7309/koncepcio.pdf [01 June 2020]

de Jong, M., Joss, S., Daan Schraven, D., Zhan, C., Margot, W. (2015). Sustainable-smart-resilient-low carbon-eco-knowledge cities; making sense of a multitude of concepts promoting sustainable urbanization. Journal of Cleaner Production, 109, 25-38. https://doi.org/10.1016/j.jclepro.2015.02.004

Desdemoustier,J., Crutzen, N., Cools, M., Teller, J. (2019). Smart City appropriation by local actors: An instrument in the making. Cities, 92, 175-186. https://doi.org/10.1016/j.cities.2019.03.021

Digitális Jólét Program (DJP 2.0) (2017). Budapest. Retrieved from: https://digitalisjoletprogram.hu/files/58/f4/58f45e44c4ebd9e53f82f56d5f44c824.pdf [01 June 2020]

Dijkstra, L.-Poelman, H. (2012). Cities in Europe: The new OECD-EC definition. Regional Focus, 1(2012), 1-13.

Echeberria, C., Barrutia, J.M., Aguado-Moralejo, I. (2020). The Smart City journey: A systematic review and future research agenda. Innovation: The European Journal of Social Science Research, 34(2), 159-201. https://doi.org/10.1080/13511610.2020.1785277

Gelei, A. (2006). A szervezet interpretatív megközelítése. Vezetéstudomány - Budapest Management Review, 38(1), 79-97. https://doi.org/10.14267/VEZTUD.2006.ksz1.08

Giffinger,R. Fertner, C.Kramar, H. Evert Meijers, E. (2007). Smart cities - Ranking of European mediumsized cities Vienna University of Technology. Retrieved from:

http://www.smart-cities.eu/download/smart_cities_final_report.pdf [21 June 2020]

Gontar, Z., Gontar, B., Pamula, A. (2013). Deployment of Smart City Concept in Poland. Selected Aspects. Management of Organizations Systematic Research, 67, 39-51.

Government of Hungary, 2017. Az „okos város”, „okos városmódszertan”fogalom meghatározásával összefüggőmódosításáról. Retrieved from: https://net.jogtar.hu/getpdf?docid=A1700056.KOR\&targetd ate=fffffff4\&printTitle=56/2017.+\%28III.+20.\%29+Korm.+rendelet\&referer=http\%3A//net.jogtar.hu/jr/ gen/hjegy_doc.cgi\%3Fdocid\%3D00000001.TXT [01 June 2020]

Government of Hungary. (2018). az okos város központi platformszolgáltatás létrehozásáról és működtetéséről. Retrieved from: https://net.jogtar.hu/jogszabaly?docid=A1800252.KOR [01 June 2020]

Győr Megyei Jogú Város Integrált Településfejleszési Stratégia. Retrieved from:

http://innovacio.gyor.hu/data/files/varosfejlesztesiosztaly/its/gymjv_its_jovahagyott_2014.09.12_javitott.pdf [01 June 2020]

Győr Megyei Jogú Város Településfejlesztési Koncepciója 2014-2030. Retrieved from: http://innovacio.gyor.hu/data/files/varosfejlesztesiosztaly/gymjv_tfk_jovahagyott_2014.09.12.pdf [01 June 2020]

Hajduk, S. (2016). The concept of a smart city in urban management. Business, Management and Education, 14(1), 34-49. https://doi.org/10.3846/bme.2016.319

Hall, R.E. (2000). The vision of a smart city. Paper presented at the 2nd International Life Extension Technology Workshop, September 28, 2000, Paris, France. Retrieved from https://www.osti.gov/servlets/purl/773961/ [09 May 2020] 
Hollands, R.G. (2008). Will the real smart city stand up: Creative, progressive, or just entrepreneurial? City, 12, 302-320. http://dx.doi.org/10.1080/13604810802479126

Janurova, M., Chaloupkova, M., Kunc, J. 2020.Smart city strategy and its implementation barriers: Czech experience. Theoretical and Empirical Researches in Urban Management, 15(2), 5-21.

Joss, S., Sengers, F., Schraven, D., Caprotti, F., Dayot, Y. (2019). The smart city as global discourse: Storylines and critical junctures across 27 cities. Journal of Urban Technology, 26(1). 3-34. https://doi.org/10.1080/10630732.2018.1558387

Kitchin, R. (2015). Making sense of smart cities: addressing present shortcomings. Cambridge Journal of Regions, Economy and Society, 8, 131-136. https://doi.org/10.1093/cjres/rsu027

Kitchin, R., Coletta,C., Evans, L., Heaphy, L., Mac Donncha, D. (2019). Smart cities, algorithmic technocracy and new urban technocrats. Planning and Knowledge: How New Forms of Technocracy are Shaping Contemporary Cities, 199-212. https://doi.org/10.2307/j.ctvkjb1z8.20

Klimovsky, D., Pinteric, U., Saparniene, D. (2016). Human limitations to introduction of smart cities: Comparative analysis from two CEE cities. Transylvanian Review of Administrative Sciences, 12(47), 80-96.

Kollar, M., Bubbico, R.L., Arsalides, N. (2018). Smart Cities, Smart Investment in Central, Eastern and South-Eastern Europe. Brussels: EIB Economics Department. Retrieved from https://www.eib.org/attachments/efs/smart_cities_smart_investments_in_cesee_en.pdf [27 July 2020]

Komninos, N., Pallot, M., Schaffers, H. (2013). Special issue on smart cities and the future internet in Europe. Journal of the Knowledge Economy, 4, 119-134. https://doi.org/10.1007/s13132-012-0083-x

Kummitha, R. (2020). Smart technologies for fighting pandemics: The techno and human driven approaches in controlling the virus transmission. Government Information Quarterly, 37(3), 101481. https://doi.org/10.1016/j.giq.2020.101481

Kunzmann, K.R. (2020). Smart Cities After COVID-19: Ten Narratives. disP - The Planning Review, 56(2), 20-31. https://doi.org/10.1080/02513625.2020.1794120

Kustra, M., Brodowicz, D.P. (2016), Implementing smart city concept in the strategic ban operations - the case of Warsaw. Conference: 11th International Forum of Knowledge Assets Dynamics 2016, Towards a New Architecture of Knowledge: Big Data, Culture and Creativity. Dresden, Germany. https://doi.org/10.13140/RG.2.1.4675.9925

Ibanescu, B.C., Banica, A., Eva, M., Cehan, A. (2020). The puzzling concept of smart city in Central and Eastern Europe: A literature review designed for policy development. Transylvanian Review of Administrative Sciences, (61), 70-88. https://doi.org/10.24193/tras.61E.4

Leitheiser, S., Follmann, A. (2020). The social innovation-(re)politicisation nexus: Unlocking the political inactually existing smart citycampaigns? The case of Smart City Cologne, Germany. Urban Studies, 57(4), 894-915. https://doi.org/10.1177/0042098019869820

Masik, G., Sagan, I., Scott, W.J. (2020). Smart City strategies and new urban development policies in the Polish context. Cities, 108, 102970. https://doi.org/10.1016/j.cities.2020.102970

Magnaghi, E., Flambard, V., Mancini,D., Jacques, J., Gouvy, N. (2021). Medium-sized smart cities: A smart vision for urban centralities and buildings. From the European case history to a proposal for the City of Parma, Italy. In E. Magnaghi, V. Flambard, D. Mancini, J. Jacques, N. Gouvy (Eds.), Organizing Smart Buildings and Cities (pp. 99-123), 36, Springer, Cham. https://doi.org/10.1007/978-3-030-60607-7_7

Meijer, A., Rodríguez Bolívar, M.P. (2016). Governing the smart city: A review of the literature on smart urban governance. International Review of Administrative Sciences, 82(2), 392-408. https://doi.org/10.1177/0020852314564308

Miskolc Megyei Jogú Város Integrált Településfejlesztési Stratégia. Retrieved from: http://miskolcvaros2020.hu/sites/default/files/dokumentumok/miskolc_its.pdf [02 July 2020]

Miskolc Megyei Jogú Város Fenntartható Energia-és Klíma Akcióterv (SECAP). Retrieved from: https://www.miskolc.hu/sites/default/files/aktualitas/csatolmany/2019-10-02/70785/miskolc_ secap_2019_09_24_2_final.pdf [02 July 2020] 
Miskolc Város Fenntartható Közlekedési Terve (SUMP). Retrieved from: http://kerekparosmiskolc.net/ wpcontent/uploads/2013/12/Miskolc_SUMP_MVK_131030_v\%C3\%A9gleges.pdf [02 July 2020]

Miskolc Megyei Jogú Város Településfejlesztési Koncepció. Retrieved from:

http://www.baz.hu/telepules/Miskolc/miskolc_mjv_telepulesfejlesztesi_koncepcioja_miskolc.pdf [02 July 2020]

Mouton, M. (2020). Worlding infrastructure in the global South: Philippine experiments and the art of being 'smart'. Urban Studies, 58(3), 621-638. https://doi.org/10.1177/0042098019891011

Nagy, E. (2012). Verseny vagy kiegyenlítés? Az európai várospolitika neoliberális fordulata és a helyi tervezési-fejlesztési gyakorlatok „projektesítése”. In: Pál V. (szerk.): A társadalomföldrajz lokális és globális kérdései. SZTE TTIK Gazdaság- és Társadalomföldrajz Tanszék, Szeged, 54-67.

Nagy, Z., Sebestyénné Szép, T., Szendi, D. (2018). Smart cityk teljesítménye a visegrádi országokban Erdélyi Társadalom, 16(1), 59-82. https://doi.org/10.17177/77171.208

Neirotti, P., De Marco, A., Cagliano, A.C., Mangano, G., Scorrano, F. (2014). Current trends in Smart City initiatives: Some stylised facts. Cities, 38, 25-36. https://doi.org/10.1016/j.cities.2013.12.010

Noori, N., Hoppe, T., de Jong, W.M. (2020). Classifying Pathways for Smart City Development: Comparing Design, Governance and Implementation in Amsterdam, Barcelona, Dubai, and Abu Dhabi. Sustainability, 12(10). https://doi.org/10.3390/su12104030

Ogrodnik, K. (2020). Multi-criteria analysis of smart cities in Poland. Geographia Polonica, 93(2), 163-181. https://doi.org/10.7163/GPol.0168

Pálné Kovács, I. (2019). A magyar önkormányzatok korlátai a helyi gazdaságfejlesztésben.

Tér és Társadalom, 33(2), 3-19. https://doi.org/10.17649/TET.33.2.3088

Panagiotopoulou, M., Stratigea, A., Kokla, M. (2019). Conceptualizing Small and Medium-Sized Smart Cities in the Mediterranean Region: An Ontological Approach. International Journal of E-planning Research, 8(4), 17-41. https://doi.org/10.4018/IJEPR.2019100102

Pašalić, I.N., Ćukušić, M., Jadrić, M. (2021). Smart city research advances in Southeast Europe. International Journal of Information Management, 58. https://doi.org/10.1016/j.ijinfomgt.2020.102127

Pécs Megyei Jogú Város Integrált Településfejlesztési Stratégia. Retrieved from: https://www.pvfzrt.hu/userfiles/dokumentumok/ITS20142020.pdf [02 July 2020]

Pécs Megyei Jogú Város Fenntartható Energia Akcióterve (SEAP). Retrieved from: https://www.pvfzrt.hu/userfiles/dokumentumok/Pecs_SEAP.pdf [02 July 2020]

Pécs Megyei Jogú Város Fenntartható Városi Mobilitás Terve (SUMP). Retrieved from: https://www.pvfzrt.hu/userfiles/dokumentumok/SUMP_2.pdf [02 July 2020

Pécs Megyei Jogú Város városfejlesztési koncepció 2014-2030. Retrieved from: https://www.pvfzrt.hu/userfiles/dokumentumok/PecsMJV_fejl_koncepcio_2014-09-2.pdf [02 July 2020]

Rechnitzer, J. (2019). Nagyvárosok a magyar területi politikában és területfejlesztésben a rendszerváltozástól napjainkig.Tér és Társadalom, 33(1), 3-26. https://doi.org/10.17649/TET.33.1.3069

Ruhlandt, R. (2018). The governance of smart cities: A systematic literature review. Cities, 81,1-23. https://doi.org/10.1016/j.cities.2018.02.014

Ruohomaa, H., Salminen, V., Kunttu, I. (2019). Towards a smart city concept in small cities. Technology Innovation Management Review, 9(9): 5-14. https://doi.org/10.22215/timreview/1264

Sallay, V., Martos, T. (2018). A Grounded Theory (GT) módszertana, Magyar Pszichológiai Szemle, 73(1/2),11-28. https://doi.org/10.1556/0016.2018.73.1.2

Sharifi, A. (2019). A critical review of selected smart city assessment tools and indicator sets. Journal of Cleaner Production, 1269-1283. https://doi.org/10.1016/j.jclepro.2019.06.172

Sikora-Fernandez, D. (2018). Smarter cities in post-socialist country: Example of Poland. Cities, 78, 52-59. https://doi.org/10.1016/j.cities.2018.03.011 
Söderström, O., Paasche, T., Klauser, F. (2014). Smart cities as corporate storytelling. City, 18(3), 307-320. https://doi.org/10.1080/13604813.2014.906716

Szalai, Á. (2020). Az okosváros-koncepció kritikai földrajzi vizsgálata - elméleti háttér és lehetséges kutatási irányok. Tér és Társadalom, 34(2), 88-107. https://doi.org/10.17649/TET.34.1.3201

Szalai, Á., Varró, K., Fabula, Sz. (2021). Towards a multiscalar perspective on the prospects of 'the actually existing smart village' - a view from Hungary. Hungarian Geographical Bulletin, 70(2), 97-112.

Szalmáné Csete, M., Buzási, A. (2020). A smart planning szerepe a fenntartható városfejlesztésben. Területi Statisztika, 60(3): 370-390. https://doi.org/10.15196/TS600304

Szeged Megyei Jogú Város Integrált Településfejlesztési Stratégiája. Retrieved from: https://www.szegedvaros.hu/letolthetocsatolmany?ID=26101\&as_attachment=1 [02 July 2020]

Szeged Megyei Jogú Város SECAP. Retrieved from: https://energiaklub.hu/files/project/Energiaklub_Szeged_SECAP_HU.pdf [02 July 2020]

Szeged Megyei Jogú Város Smart City Jövőkép és Koncepció. Retrieved from: https://www.szegedvaros.hu/letoltheto-csatolmany/?|D=20557 [02 July 2020]

Szeged Megyei Jogú Város SUMP. Retrieved from: https://www.szegedvaros.hu/letolthetocsatolmany?ID=26792\&as_attachment=1 [02 July 2020]

Szeged Megyei Jogú Város Településfejlesztési Koncepciója. Retrieved from: https://www.szegedvaros.hu/letoltheto-csatolmany/?ID=19546 [02 July 2020]

Shelton, T., Matthew, A., Wiig, A. (2015). The 'actually existing smart city.' Cambridge Journal of Regions Economy and Society, 8(1),13-25. https://doi.org/10.1093/cjres/rsu026

Valdez, A.M., Cook, M., Potter, S. (2018). Roadmaps to utopia: Tales of the smart city. Urban Studies, 55(15), 3385-3403. https://doi.org/10.1177/0042098017747857

Vanolo, A. (2014): Smartmentality: The Smart City as Disciplinary Strategy. Urban Studies, 51(5), $883-$ 898. https://doi.org/10.1177/0042098013494427

Varró, K., Bunders, D.J. (2020). Bringing back the national to the study of globally circulating policy ideas: 'Actually existing smart urbanism' in Hungary and the Netherlands. European Urban and Regional Studies, 27(3), 209-226. https://doi.org/10.1177/0969776419893731

Varró, K., Szalai, Á. (2021). Discourses and practices of the smart city in Central Eastern Europe: insights from Hungary's 'big' cities. Urban Research and Practice. https://doi.org/10.1080/17535069.2021.1904276

Vidiasova, L., Cronemberger, F. (2020). Discrepancies in perceptions of smart city initiatives in Saint Petersburg, Russia. Sustainable Cities and Society, 59. https://doi.org/10.1016/j.scs.2020.102158

Yigitcanlar, T. (2015). Smart cities: An effective urban development and management model? Australian Planner, 52, 27-34. https://doi.org/10.1080/07293682.2015.1019752

Yigitcanlar, T., Kamruzzaman, Md., Buys, L., loppolo, G., Marques, J., Da Costa, E.M., Yun, J.J. (2018). Understanding 'smart cities': Intertwining development drivers with desired outcomes in a multidimensional framework. Cities, 81, 145-160. https://doi.org/10.1016/j.cities.2018.04.003 